\title{
Oral Azelaic Acid Ester Decreases Markers of Insulin Resistance in Overweight Human Male Subjects
}

\author{
ROBERT T. STREEPER ${ }^{1 *}$, CHRISTOPHER LOUDEN ${ }^{2}$ and ELZBIETA IZBICKA ${ }^{1 *}$ \\ ${ }^{1}$ New Frontier Labs L.L.C., San Antonio, TX, U.S.A.; \\ ${ }^{2}$ Louden Consulting, Bandera, TX, U.S.A.
}

\begin{abstract}
Background/Aim: Insulin resistance (IR) is linked to increased risk of cardiovascular disease and cancer. We examined safety and efficacy of the natural product diethyl azelate (DEA) in overweight males with a varying degree of IR. Patients and Methods: Seventeen subjects [age 18-42, hemoglobin Alc (Alc) of 5.2-6.2\%] received orally $1 \mathrm{mg} / \mathrm{kg}$ DEA daily for 21 days. Blood plasma glucose, insulin and lipid levels were assessed before and after treatment. Results: DEA was well tolerated without hypoglycemia or adverse effects except transient diarrhea $(n=1)$. DEA significantly reduced fasting glucose by $6.06 \mathrm{mg} / \mathrm{dl}(n=8)$ and insulin by $37.8 \%(n=8)$ in subjects with IR and/or Alc $\geq 5.6 \%$. Furthermore, it improved cholesterol/HDL, LDL/HDL, and non-cholesterol HDL/HDL by 5.4, 6.5, and 6.6\%, respectively in all subjects, and by 8.0, 9.8, and $9.8 \%$, respectively in 9 subjects with $A l c \geq 5.6 \%$. Conclusion: DEA efficacy correlates with the degree of IR. DEA holds promise as a novel treatment for the management of IR.
\end{abstract}

Azelaic acid and its esters, azelates, occur naturally in plants, animals, and humans. We discovered that the naturally occurring fatty acid ester, diethyl azelate (DEA) (1), can be used for the treatment of diet- and ethanol-induced insulin resistance (IR), the hallmark of metabolic syndrome, prediabetes and Type 2 diabetes (T2D). A number of studies (2-4) have shown a correlation of metabolic diseases with increased risk of cancer, especially liver, pancreatic and endometrial (5-7).

The Western diet combined with a sedentary lifestyle results in chronic metabolic inflammation $(8,9)$. A diet

This article is freely accessible online.

*These Authors contributed equally to this work.

Correspondence to: Elzbieta Izbicka, New Frontier Labs L.L.C., 9901 IH10 West, suite 800, San Antonio, TX 78230, U.S.A. Tel: +1 2107256868, e-mail: eizbicka.g4@gmail.com

Key Words: Insulin resistance, azelaic acid ester, metabolic syndrome, type 2 diabetes, cardiovascular disease, cancer, metformin, metaflammation, dyslipidemia, lipids, obesity. consisting of $\sim 50 \%$ carbohydrates with high levels of fructose has been shown to induce IR in healthy non-obese men within 2-7 days (10). The detrimental health effects of dietary fructose are similar to those of ethanol (11). The diabetogenic effects of ethanol consumption, either acute (12) or chronic (13), strongly correlate with the development of IR in a dose-dependent manner $(14,15)$.

Current T2D treatments do not reduce the incidence of or cure T2D and have side effects that range from mild to lifethreatening, in some cases warranting 'Black Box' warnings mandated by the Food and Drug Administration of the United States of America (US FDA). Therapies available to patients with type T2D after metformin failure have been shown to induce weight gain, cause hypoglycemia or show poor long-term efficacy (16). No T2D drugs address the progressive nature of the disease and the underlying causes of IR. There is a need for agents with prolonged efficacy, superior disease modification power, and improved safety.

DEA and other azelates are metabolic products occurring naturally in humans and other mammals $(17,18)$. Azelates are also present in grains and grain-derived products including liquors (19), and in fermented foods due to bacterial degradation of acyl glycerol fatty acids and esterification of the resulting medium chain fatty acids (20). Fermentation of olives by Lactobacilli to render them edible has been practiced for at least 6 millennia in the Mediterranean basin (21). The Lactobacilli destroy bitter alkaloids contained in olive fruits, converting them to table olives (22). In addition, the Lactobacilli ferment some of the oleic acid contained in the olives into azelaic acid and azelates. The rind of olives also contains appreciable quantities of azelaic acid. Fermented soybean products, produced by humans for over 3 millennia (23), may help prevent or attenuate the progression of T2D (24). Notably, nonfermented soybean products have no effect on IR (24). Azelaic acid and azelate ethyl esters are present in douchi, a fermented black bean product (25). Although not currently used as drugs, azelates and similar fatty acid esters are used as food additives, lubricants and plasticizers. DEA is approved as a flavoring additive in the European Union (26, 27) and diethylhexyl azelate is approved for food contact 
packaging in the United States. A closely related ester, diethyl sebacate, which differs from DEA in that sebacic acid is one methylene unit longer than azelaic acid, is on the list of generally regarded as safe (GRAS) compounds (28) and the inactive ingredients list (29) of the US FDA.

The purpose of our study was to evaluate the effects of DEA on certain surrogate markers of IR, namely, blood plasma glucose, insulin and lipids (30), when administered orally to overweight or obese adult male volunteers. The cohort spanned from normal to prediabetic subjects based on the levels of the blood marker glycated hemoglobin A1c (A1c), which is considered a longer-term gauge of blood glucose control (31). The American Diabetes Association defines prediabetes as an A1c of 5.7\%-6.4\%, but also states that patients with an A1c just below the $5.7 \%$ threshold are at risk of developing diabetes (32). Our study has demonstrated that DEA can significantly improve the condition of subjects with IR.

\section{Patients and Methods}

DEA was synthesized from azelaic acid and ethyl alcohol using the standard acid-catalyzed esterification followed by fractional distillation to $99 \%$ purity as determined by gas chromatographymass spectrometry (GC-MS). The human studies were performed with the approval of the Institutional Review Board at IntegReview (Austin, TX, USA). Consent was obtained from study subjects following the informed consent protocol EP20160001. The Board was constituted and operated in accordance with the ethical rules of the Helsinki Declaration and requirements as described in the US Code of Federal Regulations 21 CFR Part 56.

Seventeen subjects were recruited by sampling a large population at risk for T2D according to convenience sample; a statistical method of drawing representative data (33) to measure the changes in glucose, lipid and insulin measurements after an oral glucose tolerance test (OGTT) after the subjects had been treated for 21 days.

The subjects were overweight to obese males with body mass indices (BMI) ranging from 27.2 to $43.6 \mathrm{~kg} / \mathrm{m}^{2}$, glycated hemoglobin A1c (HbA1c) of 5.0-6.2\% and insulin levels of 8.8-52 $\mu \mathrm{U} / \mathrm{ml}$. The study was conducted by Clinical Trials of Texas, Inc. in San Antonio, TX, USA. The cohort represented a population at risk for the development of T2D. The study was restricted to male participants to control for the variability of insulin sensitivity associated with the menstrual cycle (34). The subjects received 21 daily oral doses (q1d) of $1 \mathrm{mg} / \mathrm{kg}$ DEA. A fasting OGTT was performed on Day 0 and again on Day 21, and glucose measurements were performed at $-30,-5$ and $0 \mathrm{~min}$, insulin levels at -30 and $0 \mathrm{~min}$ and both glucose and insulin levels at 30,60, 90, 120 and $180 \mathrm{~min}$. The $180 \mathrm{~min}$ time point was selected to gain an early insight into the possible drug action (35). Blood lipid levels (triglycerides, cholesterol, HDL, non-cholesterol HDL and LDL) were measured before the onset of treatment on Day 0 and again on Day 21. The error of the assays was $<5 \%$ (36).

The results of the various marker measurements at Day 0 and Day 21 were compared using both the paired Students $t$-test and the Wilcoxon signed rank test. The results of both calculations are provided; the $p$-value from the paired Student $t$-test first, followed by the $p$-value from the Wilcoxon signed rank test. Generalized Estimating Equations and bootstrapping were used to verify the results generated with other methods. Fasting glucose was calculated as the average of the $-30,-5$ and 0 min measurements and fasting insulin was calculated as the average of the -30 and 0 min measurements. Spearman's correlation coefficient was calculated for the relationship between A1c and pre-treatment fasting plasma glucose versus post-treatment fasting plasma glucose. Area under the curve (AUC) was calculated over the 180 min time span of the OGTT. All analyses were performed using the open language engine $\mathrm{R}$ 3.4.4. Statistical significance was set at the $\alpha=0.05$ level.

\section{Results}

Daily oral DEA was well tolerated by all study subjects; and only one individual experienced transient mild diarrhea in the first week of treatment. No other adverse effects were reported. Specific effects of DEA on examined endpoints are summarized in Table I and presented in detail below.

Glucose: The levels of A1c were measured to assess the effects of oral antidiabetic agents on glucose control with the drug activity becoming apparent within the first 4 to 6 months (37). We did not expect a measurable effect on A1c in this short-term study. Instead, the pre-treatment A1c levels were examined to assess the relative state of IR in the subjects. Then, the cohort was sorted by descending A1c values (Figure 1A), 3 subjects with A1c's of 6.2, 6.1 and $6.0 \%$ were classified as prediabetic and 6 subjects with A1c's of 5.6-5.7\% as having an increased risk for T2D. This subgroup of 9 subjects with A1c $\geq 5.6 \%$ is referred to as 'high A1c' herein. The remaining 8 subjects with A1c's of $5.0-5.4 \%$ having a lower risk for $\mathrm{T} 2 \mathrm{D}$ were referred to as 'low A1c'. Stratification by fasting plasma glucose levels (Figure 1B) showed that 9 subjects had $\geq 100 \mathrm{mg} / \mathrm{dl}$ ("high glucose') and 8 subjects were below the threshold of 100 $\mathrm{mg} / \mathrm{ml}$ ('low glucose').

For measuring the effect of DEA on blood glucose, we relied on assessment of fasting plasma glucose levels, a measure that is commonly used as an indication that a subject may be diabetic. A level under $100 \mathrm{mg} / \mathrm{dl}$ is considered clinically normal (38) while the range between 100 and $125 \mathrm{mg} / \mathrm{dl}$ is indicative of prediabetes (39). At the threshold of $100 \mathrm{mg} / \mathrm{dl}$ the human body begins to have a compromised IR to glucose shock (40). We used the oral glucose tolerance test (OGTT) whereby a standard dose of glucose is ingested by mouth and blood samples are taken afterward for measurements of blood glucose as a means of understanding the pharmacodynamic effects of DEA.

When the entire cohort of 17 subjects was analyzed as a group, post-treatment fasting glucose increased slightly yet insignificantly by $0.11 \mathrm{mg} / \mathrm{dl}(p=0.962 ; p=0.96)$. However, fasting glucose decreased in subjects both in the high glucose and high $\mathrm{A} 1 \mathrm{c}$ groups. For those with an $\mathrm{HbA} 1 \mathrm{c} \geq 5.6 \%$, the 
Table I. Variables (geometric mean and 95\% confidence limits) determined during a 21-day's study of diethylazelate in overweight male subjects.

\begin{tabular}{|c|c|c|c|c|c|c|c|c|c|c|}
\hline \multirow[t]{2}{*}{ Variable } & \multicolumn{2}{|c|}{ All $(n=17)$} & \multicolumn{2}{|c|}{ Low A1c $(n=8)$} & \multicolumn{2}{|c|}{ High A1c $(n=9)$} & \multicolumn{2}{|c|}{ FPG <100 mg/dl $(\mathrm{n}=8)$} & \multicolumn{2}{|c|}{ FPG $>100 \mathrm{mg} / \mathrm{dl}(\mathrm{n}=9)$} \\
\hline & D0 & D21 & D0 & D21 & D0 & D21 & D0 & D21 & D0 & D21 \\
\hline Fasting plasma & 101.662 & 99.732 & 97.731 & 99.138 & 105.156 & 100.261 & 92.769 & 97.25 & 109.567 & $101.939 * *$ \\
\hline $\begin{array}{l}\text { glucose } \\
(\mathrm{mg} / \mathrm{dl})\end{array}$ & $\begin{array}{l}(90.113 \\
113.211)\end{array}$ & $\begin{array}{l}(92.462, \\
107.002)\end{array}$ & $\begin{array}{l}(86.515, \\
108.947)\end{array}$ & $\begin{array}{l}(92.916, \\
105.359)\end{array}$ & $\begin{array}{l}(93.863, \\
116.448)\end{array}$ & $\begin{array}{l}(91.825, \\
108.697)\end{array}$ & $\begin{array}{l}(85.484, \\
100.053)\end{array}$ & $\begin{array}{l}(90.903, \\
103.597)\end{array}$ & $\begin{array}{c}(101.143, \\
117.99)\end{array}$ & $\begin{array}{l}(94.269 \\
109.609)\end{array}$ \\
\hline Glucose 180 & 100.315 & 91.579 & 90.569 & 87.588 & 108.978 & 95.128 & 89.919 & 86.494 & 109.556 & 96.1 \\
\hline $\min (\mathrm{mg} / \mathrm{dl})$ & $\begin{array}{l}(66.998, \\
133.631)\end{array}$ & $\begin{array}{l}(62.923 \\
120.236)\end{array}$ & $\begin{array}{l}(72.025 \\
109.113)\end{array}$ & $\begin{array}{c}(72.575 \\
102.6)\end{array}$ & $\begin{array}{l}(67.269 \\
150.687)\end{array}$ & $\begin{array}{c}(57.51, \\
132.745)\end{array}$ & $\begin{array}{l}(71.388, \\
108.45)\end{array}$ & $\begin{array}{l}\text { (71.181, } \\
101.807)\end{array}$ & $\begin{array}{l}(68.139 \\
150.972)\end{array}$ & $\begin{array}{l}(58.839, \\
133.361)\end{array}$ \\
\hline AUC Glucose & $\begin{array}{c}25.826 \\
(20.758 \\
30.894)\end{array}$ & $\begin{array}{c}25.356 \\
(20.152 \\
30.559)\end{array}$ & $\begin{array}{c}24.153 \\
(21.644 \\
26.663)\end{array}$ & $\begin{array}{c}24.756 \\
(23.040 \\
26.471)\end{array}$ & $\begin{array}{c}27.313 \\
(20.944 \\
33.682)\end{array}$ & $\begin{array}{c}25.889 \\
(18.754 \\
33.023)\end{array}$ & $\begin{array}{c}23.53 \\
(21.166 \\
25.894)\end{array}$ & $\begin{array}{c}24.475 \\
(19.643 \\
29.307)\end{array}$ & $\begin{array}{c}27.867 \\
(21.824 \\
33.910)\end{array}$ & $\begin{array}{c}26.138 \\
(20.459 \\
31.818)\end{array}$ \\
\hline $\begin{array}{l}\text { Fasting insulin } \\
(\mu \mathrm{U} / \mathrm{ml})\end{array}$ & $\begin{array}{c}26.082 \\
(10.065 \\
42.1)\end{array}$ & $\begin{array}{l}25.894 \\
(3.064, \\
48.724)\end{array}$ & $\begin{array}{c}21.212 \\
(12.172 \\
30.253)\end{array}$ & $\begin{array}{c}22.512 \\
(10.835 \\
34.19)\end{array}$ & $\begin{array}{c}30.411 \\
(10.492 \\
50.331)\end{array}$ & $\begin{array}{c}28.9 \\
(-1.125 \\
58.925)\end{array}$ & $\begin{array}{l}20.212 \\
(8.336, \\
32.089)\end{array}$ & $\begin{array}{c}20.95 \\
(8.242 \\
33.658)\end{array}$ & $\begin{array}{c}31.3 \\
(13.283 \\
49.317)\end{array}$ & $\begin{array}{c}30.289 \\
(1.05 \\
59.528)\end{array}$ \\
\hline AUC insulin & $\begin{array}{c}24.963 \\
(15.288 \\
34.637)\end{array}$ & $\begin{array}{c}26.834 \\
(14.646 \\
39.021)\end{array}$ & $\begin{array}{c}22.609 \\
(14.285 \\
30.932)\end{array}$ & $\begin{array}{c}27.785 \\
(14.299 \\
41.271)\end{array}$ & $\begin{array}{c}27.055 \\
(16.280 \\
37.830)\end{array}$ & $\begin{array}{c}25.988 \\
(14.315 \\
37.660)\end{array}$ & $\begin{array}{c}22.215 \\
(11.805 \\
32.625)\end{array}$ & $\begin{array}{c}27.461 \\
(12.317 \\
42.605)\end{array}$ & $\begin{array}{c}27.405 \\
(18.567 \\
36.243)\end{array}$ & $\begin{array}{c}26.275 \\
(16.494 \\
36.056)\end{array}$ \\
\hline $\begin{array}{l}\text { Cholesterol, } \\
\text { total }(\mathrm{mg} / \mathrm{dl})\end{array}$ & $\begin{array}{c}150.118 \\
(104.379 \\
195.856)\end{array}$ & $\begin{array}{c}148.882 \\
(101.074 \\
196.69)\end{array}$ & $\begin{array}{c}129.5 \\
(86.608 \\
172.392)\end{array}$ & $\begin{array}{r}125.5 \\
(72.38 \\
178.62)\end{array}$ & $\begin{array}{c}168.444 \\
(126.358, \\
210.531)\end{array}$ & $\begin{array}{c}169.667 \\
(136.963 \\
202.37)\end{array}$ & $\begin{array}{l}154.875 \\
(98.406 \\
211.344)\end{array}$ & $\begin{array}{l}146.125 \\
(81.035 \\
211.215)\end{array}$ & $\begin{array}{c}145.889 \\
(109.131 \\
182.646)\end{array}$ & $\begin{array}{c}151.333 \\
(122.183 \\
180.484)\end{array}$ \\
\hline $\begin{array}{l}\text { LDL cholesterol } \\
(\mathrm{mg} / \mathrm{dl})\end{array}$ & $\begin{array}{r}93.765 \\
(61.047 \\
126.482)\end{array}$ & $\begin{array}{c}89.765 \\
(57.062 \\
122.467)\end{array}$ & $\begin{array}{r}81.125 \\
(54.698 \\
107.552)\end{array}$ & $\begin{array}{c}74.375 \\
(45.045 \\
103.705)\end{array}$ & $\begin{array}{c}105 \\
(69.957 \\
140.043)\end{array}$ & $\begin{array}{c}103.444 \\
(72.805 \\
134.084)\end{array}$ & $\begin{array}{c}101 \\
(62.344 \\
139.656)\end{array}$ & $\begin{array}{c}90.75 \\
(49.127 \\
132.373)\end{array}$ & $\begin{array}{c}105 \\
(69.957 \\
140.043)\end{array}$ & $\begin{array}{c}103.444 \\
(72.805 \\
134.084)\end{array}$ \\
\hline $\begin{array}{l}\text { HDL cholesterol } \\
(\mathrm{mg} / \mathrm{dl})\end{array}$ & $\begin{array}{c}32.765 \\
(22.273 \\
43.256)\end{array}$ & $\begin{array}{c}34.412 \\
(22.653 \\
46.17)\end{array}$ & $\begin{array}{c}27 \\
(16.033 \\
37.967)\end{array}$ & $\begin{array}{c}26.75 \\
(13.858 \\
39.642)\end{array}$ & $\begin{array}{l}37.889 \\
(30.67 \\
45.108)\end{array}$ & $\begin{array}{c}41.222 \\
(36.728 \\
45.716)\end{array}$ & $\begin{array}{c}31.25 \\
(17.847 \\
44.653)\end{array}$ & $\begin{array}{c}31.5 \\
(14.887 \\
48.113)\end{array}$ & $\begin{array}{c}34.111 \\
(26.455 \\
41.767)\end{array}$ & $\begin{array}{c}37 \\
(32.641 \\
41.359)\end{array}$ \\
\hline $\begin{array}{l}\text { Non-cholesterol } \\
\text { HDL (mg/dl) }\end{array}$ & $\begin{array}{c}117.412 \\
(80.052 \\
154.772)\end{array}$ & $\begin{array}{l}114.471 \\
(76.013 \\
152.929)\end{array}$ & $\begin{array}{c}102.5 \\
(67.958 \\
137.042)\end{array}$ & $\begin{array}{c}98.75 \\
(55.996 \\
141.504)\end{array}$ & $\begin{array}{l}130.667 \\
(94.232 \\
167.102)\end{array}$ & $\begin{array}{l}128.444 \\
(98.582 \\
158.307)\end{array}$ & $\begin{array}{l}111.778 \\
(80.892 \\
142.664)\end{array}$ & $\begin{array}{c}114.333 \\
(87.278 \\
141.389)\end{array}$ & $\begin{array}{l}123.75 \\
(78.88, \\
168.62)\end{array}$ & $\begin{array}{c}114.625 \\
(64.187 \\
165.063)\end{array}$ \\
\hline $\begin{array}{l}\text { Triglycerides } \\
(\mathrm{mg} / \mathrm{dl})\end{array}$ & $\begin{array}{c}118.588 \\
(77.926 \\
159.25)\end{array}$ & $\begin{array}{c}124 \\
(73.094 \\
174.906)\end{array}$ & $\begin{array}{l}106.875 \\
(57.756 \\
155.994)\end{array}$ & $\begin{array}{l}122.625 \\
(49.036 \\
196.214)\end{array}$ & $\begin{array}{c}129 \\
(98.398 \\
159.602)\end{array}$ & $\begin{array}{c}125.222 \\
(104.229 \\
146.215)\end{array}$ & $\begin{array}{c}122.889 \\
(89.197 \\
156.58)\end{array}$ & $\begin{array}{c}127.667 \\
(87.911 \\
167.422)\end{array}$ & $\begin{array}{c}113.75 \\
(64.441 \\
163.059)\end{array}$ & $\begin{array}{c}119.875 \\
(55.999 \\
183.751)\end{array}$ \\
\hline $\begin{array}{l}\text { Cholesterol, } \\
\text { total/HDL }\end{array}$ & $\begin{array}{l}4.806 \\
(3.68, \\
5.931)\end{array}$ & $\begin{array}{c}\mathbf{4 . 5 5 3 *} \\
(3.426, \\
5.68)\end{array}$ & $\begin{array}{c}5.2 \\
(3.746 \\
6.654)\end{array}$ & $\begin{array}{c}5.062 \\
(3.672 \\
6.453)\end{array}$ & $\begin{array}{c}4.456 \\
(3.831, \\
5.08)\end{array}$ & $\begin{array}{c}\mathbf{4 . 1}^{*} \\
(3.502, \\
4.698)\end{array}$ & $\begin{array}{c}4.311 \\
(3.621, \\
5.001)\end{array}$ & $\begin{array}{c}4.089 \\
(3.358, \\
4.819)\end{array}$ & $\begin{array}{c}5.362 \\
(4.065, \\
6.66)\end{array}$ & $\begin{array}{c}5.075 \\
(3.769, \\
6.381)\end{array}$ \\
\hline LDL/HDL & $\begin{array}{c}3.442 \\
(2.481 \\
4.403)\end{array}$ & $\begin{array}{l}\text { 3.201* } \\
(2.31 \\
4.092)\end{array}$ & $\begin{array}{c}3.744 \\
(2.543 \\
4.944)\end{array}$ & $\begin{array}{c}3.582 \\
(2.543 \\
4.621)\end{array}$ & $\begin{array}{c}3.173 \\
(2.531 \\
3.816)\end{array}$ & $\begin{array}{c}\mathbf{2 . 8 6 2} * * \\
(2.255 \\
3.47)\end{array}$ & $\begin{array}{c}3.082 \\
(2.383, \\
3.78)\end{array}$ & $\begin{array}{c}2.892 \\
(2.224, \\
3.559)\end{array}$ & $\begin{array}{c}3.847 \\
(2.752, \\
4.942)\end{array}$ & $\begin{array}{c}3.549 \\
(2.527, \\
4.571)\end{array}$ \\
\hline $\begin{array}{l}\text { LDL/ } \\
\text { triglycerides }\end{array}$ & $\begin{array}{c}0.998 \\
(0.562 \\
1.434)\end{array}$ & $\begin{array}{c}0.893 \\
(0.619, \\
1.166)\end{array}$ & $\begin{array}{c}1.048 \\
(0.471, \\
1.624)\end{array}$ & $\begin{array}{c}0.804 \\
(0.556 \\
1.051)\end{array}$ & $\begin{array}{c}0.954 \\
(0.664, \\
1.244)\end{array}$ & $\begin{array}{c}0.972 \\
(0.687, \\
1.256)\end{array}$ & $\begin{array}{c}0.861 \\
(0.669, \\
1.054)\end{array}$ & $\begin{array}{c}0.887 \\
(0.612, \\
1.161)\end{array}$ & $\begin{array}{c}1.152 \\
(0.568 \\
1.735)\end{array}$ & $\begin{array}{c}0.9 \\
(0.608, \\
1.191)\end{array}$ \\
\hline Non-cholesterol & 3.799 & $3.549 *$ & 4.196 & 4.046 & 3.446 & 3.108 & 3.309 & 3.098 & 4.349 & 4.057 \\
\hline HDL/HDL & $\begin{array}{l}(2.68 \\
4.917)\end{array}$ & $\begin{array}{l}(2.434, \\
4.664)\end{array}$ & $\begin{array}{l}(2.758 \\
5.633)\end{array}$ & $\begin{array}{l}(2.666 \\
5.426)\end{array}$ & $\begin{array}{l}(2.816 \\
4.077)\end{array}$ & $\begin{array}{l}(2.512, \\
3.704)\end{array}$ & $\begin{array}{l}(2.624, \\
3.995)\end{array}$ & $\begin{array}{l}(2.376, \\
3.819)\end{array}$ & $\begin{array}{l}(3.058, \\
5.641)\end{array}$ & $\begin{array}{l}(2.757, \\
5.357)\end{array}$ \\
\hline $\begin{array}{l}\text { Triglycerides/ } \\
\text { HDL }\end{array}$ & $\begin{array}{l}3.761 \\
(2.399 \\
5.123)\end{array}$ & $\begin{array}{l}3.907 \\
(2.227 \\
5.588)\end{array}$ & $\begin{array}{l}4.076 \\
(2.299 \\
5.854)\end{array}$ & $\begin{array}{c}4.82 \\
(2.816 \\
6.824)\end{array}$ & $\begin{array}{c}3.481 \\
(2.611 \\
4.35)\end{array}$ & $\begin{array}{l}3.096 \\
(2.35 \\
3.843)\end{array}$ & $\begin{array}{l}3.693 \\
(2.618, \\
4.769)\end{array}$ & $\begin{array}{l}3.521 \\
(2.135, \\
4.907)\end{array}$ & $\begin{array}{l}3.837 \\
(2.133 \\
5.541)\end{array}$ & $\begin{array}{l}4.342 \\
(2.38 \\
6.304)\end{array}$ \\
\hline
\end{tabular}

D0: Day 0, pre-treatment values; D21: Day 21, post-treatment values; AUC: area under the curve; FPG: fasting plasma glucose; LDL: low density lipoprotein; HDL: high density lipoprotein; Values without paretheses: mean; Values in parentheses: $95 \%$ confidence intervals. ${ }^{*} p<0.05$; bold type. ${ }^{* *} p<0.01$; bold type.

average decrease was $4.25 \mathrm{mg} / \mathrm{dl}(p=0.128 ; p=0.22)$. The largest decrease occurred in the 8 subjects with a fasting glucose $\geq 100 \mathrm{mg} / \mathrm{dl}$ in whom the fasting glucose decreased by an average $6.06 \mathrm{mg} / \mathrm{dl}(p=0.033 ; p=0.06)$, see also Figure $2 \mathrm{~A}$. The decrease in fasting glucose after treatment was moderately correlated with the pre-treatment A1c $(p=-0.551)$ and strongly correlated with the fasting plasma glucose pretreatment ( $p=-0.755)$ (Figure 2B and 2C).

Modulation of postprandial glucose level is of interest for drug development (41) given that even transient hyperglycemia 


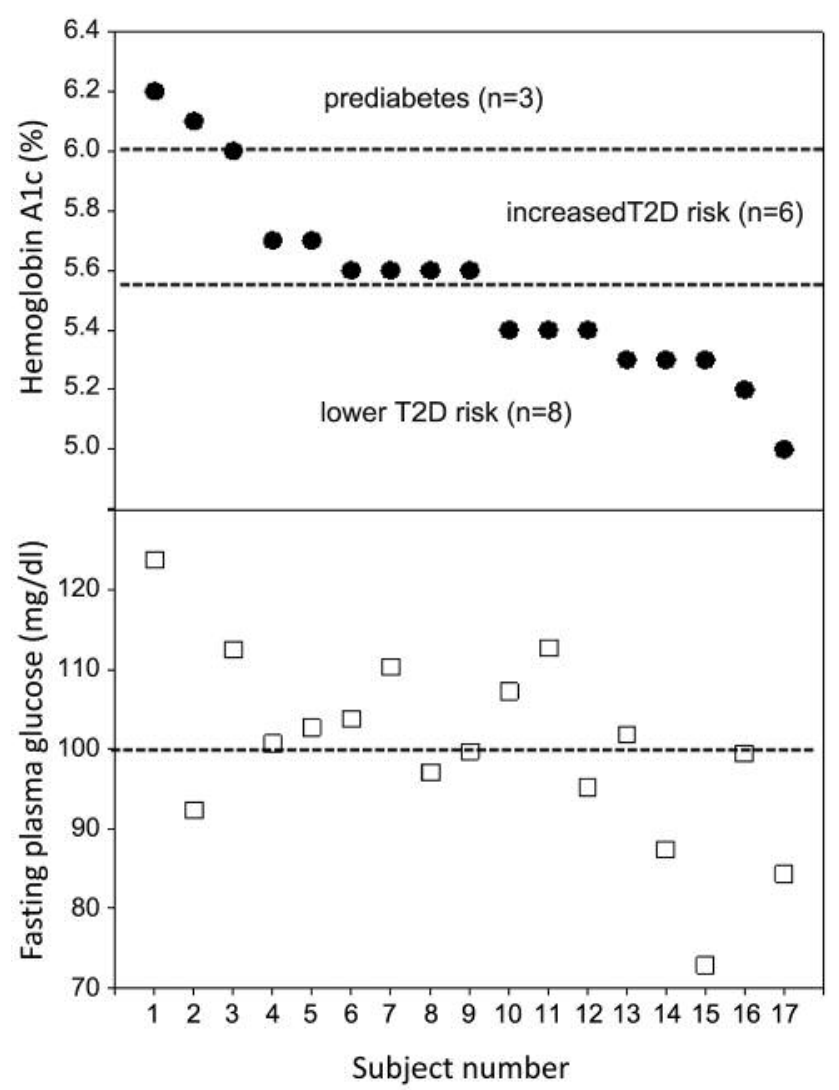

Figure 1. Stratification of the study cohort of 17 subjects by glucose markers. A; stratification by descending hemoglobin Alc levels, filled circles. B; corresponding fasting plasma glucose levels; open squares.

has long-term impact on cardiovascular and kidney diseases, neuropathy and retinopathy $(42,43)$. Figure $3 \mathrm{~A}$ shows the effects of DEA on glucose at $180 \mathrm{~min}$ in the high and low A1c groups. In a subset of 12 subjects, DEA decreased glucose levels at $180 \mathrm{~min}$, compared to the average pre-OGTT glucose levels on Day 21 , by $2.4 \%$ to $31.5 \%$ with an average decrease of $21.7 \%(p<0.001$; median decrease $25.3 \%)$. For the entire cohort, the average decrease at $180 \mathrm{~min}$ was not significant $(9.14 \% ; p=0.136 ; 0.057$ ) due to a single outlier (subject \#1) who showed a $58.6 \%$ increase. This particular subject had an average fasting insulin of $77.45 \mu \mathrm{U} / \mathrm{ml}$ and may have been leptin resistant (44) which may interfere with the putative mechanism of action of DEA (unpublished data). Excluding that subject, the remaining 16 subjects exhibited a decrease in $180 \mathrm{~min}$ plasma glucose of $13.5 \%$ after treatment $(p=0.002 ; 0.003)$.

The effects of DEA can be appreciated by the analysis of three individual prediabetic cases. As shown in Figure 3B, the glucose disposal profile of subject \#1 (A1c 6.2\%) increased posttreatment but the fasting and $180 \mathrm{~min}$ glucose levels decreased from 123.8 to $116.3 \mathrm{mg} / \mathrm{dl}$ and from 200.0 to $184.5 \mathrm{mg} / \mathrm{dl}$, respectively. Subjects \#2 (A1c 6.1\%) and \#3 (A1c 6.0\%) experienced improvement in glucose clearance rates at $180 \mathrm{~min}$ (from 88.3 to $69 \mathrm{mg} / \mathrm{dl}$ and from 146 to $119 \mathrm{mg} / \mathrm{dl}$, respectively).

Insulin: In the prediabetic state and more so in $\mathrm{T} 2 \mathrm{D}$, the body does not respond to insulin properly leading to IR. Subjects with IR show elevated blood glucose and insulin levels. In our study, fasting insulin spanned mostly normal ranges of $<25$ $\mu \mathrm{U} / \mathrm{ml}$ before and after the treatment in the high and low A1c groups (Figure 4A) and the inter-group differences were not significant. An outlier was a single subject (\#1) in the high A1c group (Figure 4B) whose pre-treatment average fasting insulin increased post-treatment from $77.45 \mu \mathrm{U} / \mathrm{ml}$ to $96.15 \mu \mathrm{U} / \mathrm{ml}$. The remaining 16 subjects experienced a decrease of fasting insulin of $13.4 \%(p=0.007 ; 0.009)$

In a subset of 8 subjects (\#2-4, 8-11, and 13) from both high and low $(\geq 5.3 \%)$ A1c groups, DEA treatment significantly $(p=0.004, p=0.008)$ decreased mean fasting insulin by $37.8 \%$ (a median decrease of $42.5 \%$ ). The apparent non-responders including the outlier (subject \#1) had otherwise either normal pre-treatment levels of fasting insulin, plasma glucose, and/or lipid markers. Considering all 17 subjects, the decrease was $0.7 \mu \mathrm{U} / \mathrm{ml}(p=0.916 ; p=0.963)$. In the high fasting plasma glucose group, the decrease was $2.97 \mu \mathrm{U} / \mathrm{ml}(p=0.752 ; p=0.855)$ and in the high A1c group, the decrease was $0.84 \mu \mathrm{U} / \mathrm{ml}(p=0.916 ; p=0.963)$.

The effects of treatment on individual insulin profiles in 3 prediabetic subjects (Figure 4B) parallel their glucose response (Figure 3B) and suggest that in cases such as subject \#1 with advanced prediabetes, the dose and/or duration of the treatment need to be further optimized.

The median insulin AUC decreased by 1663.5 in the high A1c group but increased by 3380.25 in the low A1c group. Neither change was statistically significant. The glucose and insulin responses to DEA were correlated for the entire cohort. Overall, DEA increased the correlation between AUCs for glucose and insulin from 0.229 pre-treatment to 0.523 post-treatment (data not shown).

Lipid panel: When the lipid data were analyzed for the entire cohort, DEA did not exert statistically significant effects on any endpoint considered singly: total cholesterol, LDL, HDL, non-cholesterol HDL, and triglycerides (Table I). However, the pharmacological effects of DEA become noticeable between the high and low A1c groups (Figure 5A-E). Abnormal total cholesterol (>200 mg/dl) in two subjects in the high A1c group decreased or returned to normal levels. The median total cholesterol decreased by $1 \mathrm{mg} / \mathrm{dl}$ in the high A 1c group but increased by $9 \mathrm{mg} / \mathrm{dl}$ in the low A1c group (Figure 5A). LDL showed a decreasing trend toward normal values of $<100 \mathrm{mg} / \mathrm{dl}$ in the high A1c group but less so in the low A1c group (Figure 5B). HDL and non- cholesterol HDL were within the normal range $(>40 \mathrm{mg} / \mathrm{dl}$ and $<130 \mathrm{mg} / \mathrm{dl})$ in all subjects and were non-significantly affected by the 

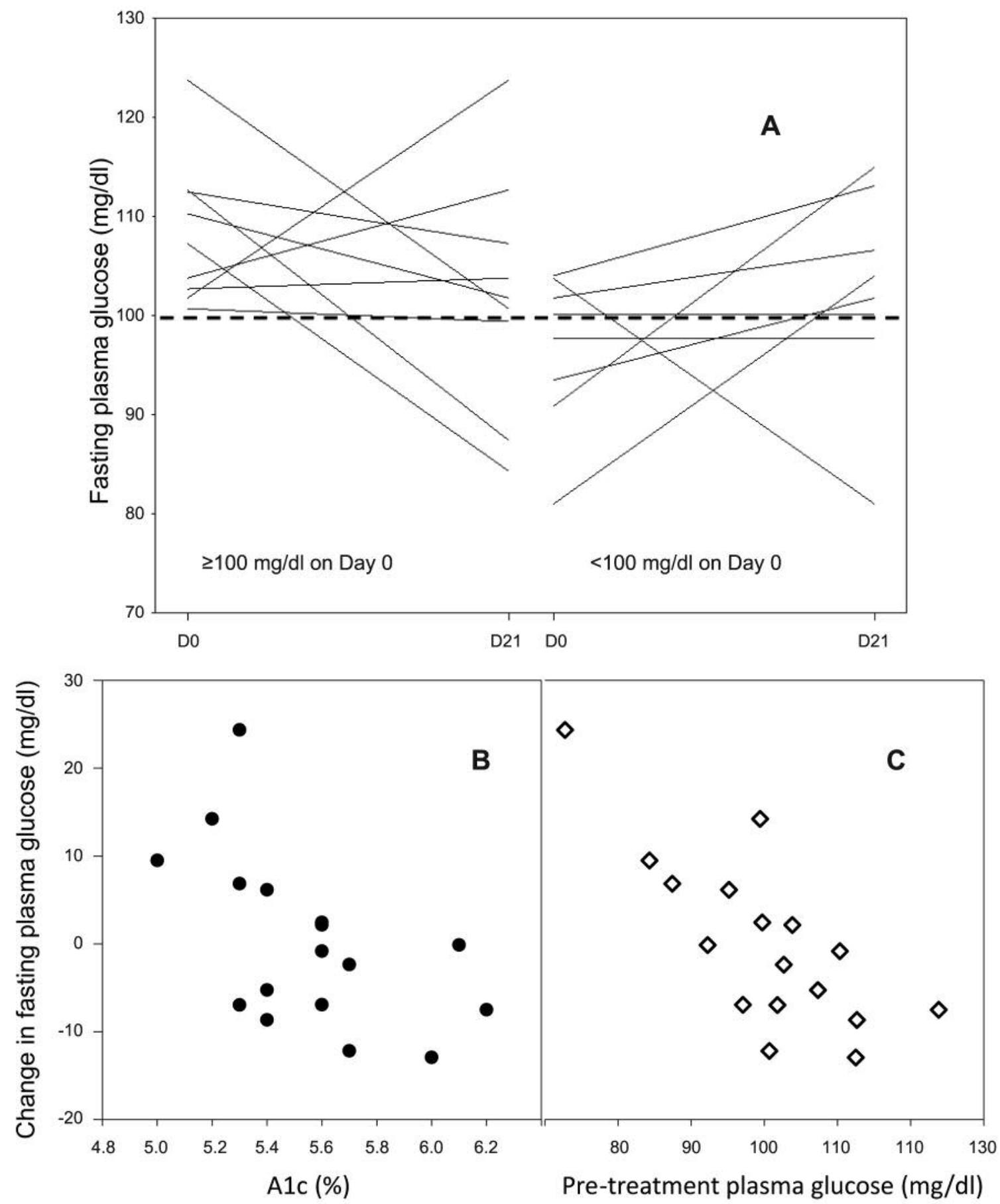

Figure 2. Effects of DEA on fasting plasma glucose. A; glucose levels in the subgroup of subjects with $\geq 100 \mathrm{mg} / \mathrm{dl}$ and $<100 \mathrm{mg} / \mathrm{dl}$ pre-treatment. $B$; correlation of glucose levels after treatment with the fasting plasma glucose pre-treatment and C; with hemoglobin Alc levels.

treatment (Figure 5C, D). Elevated triglycerides decreased post-treatment to normal levels in 8 subjects including two subjects with abnormal triglycerides of $>150 \mathrm{mg}$ before treatment in the high A1c group (Figure 5E).
In contrast, substantial differences were observed in the lipid ratios. While the total cholesterol remained largely unaffected by DEA treatment, the ratio of total cholesterol/HDL decreased significantly by $5.36 \% \quad(p=0.025$; 

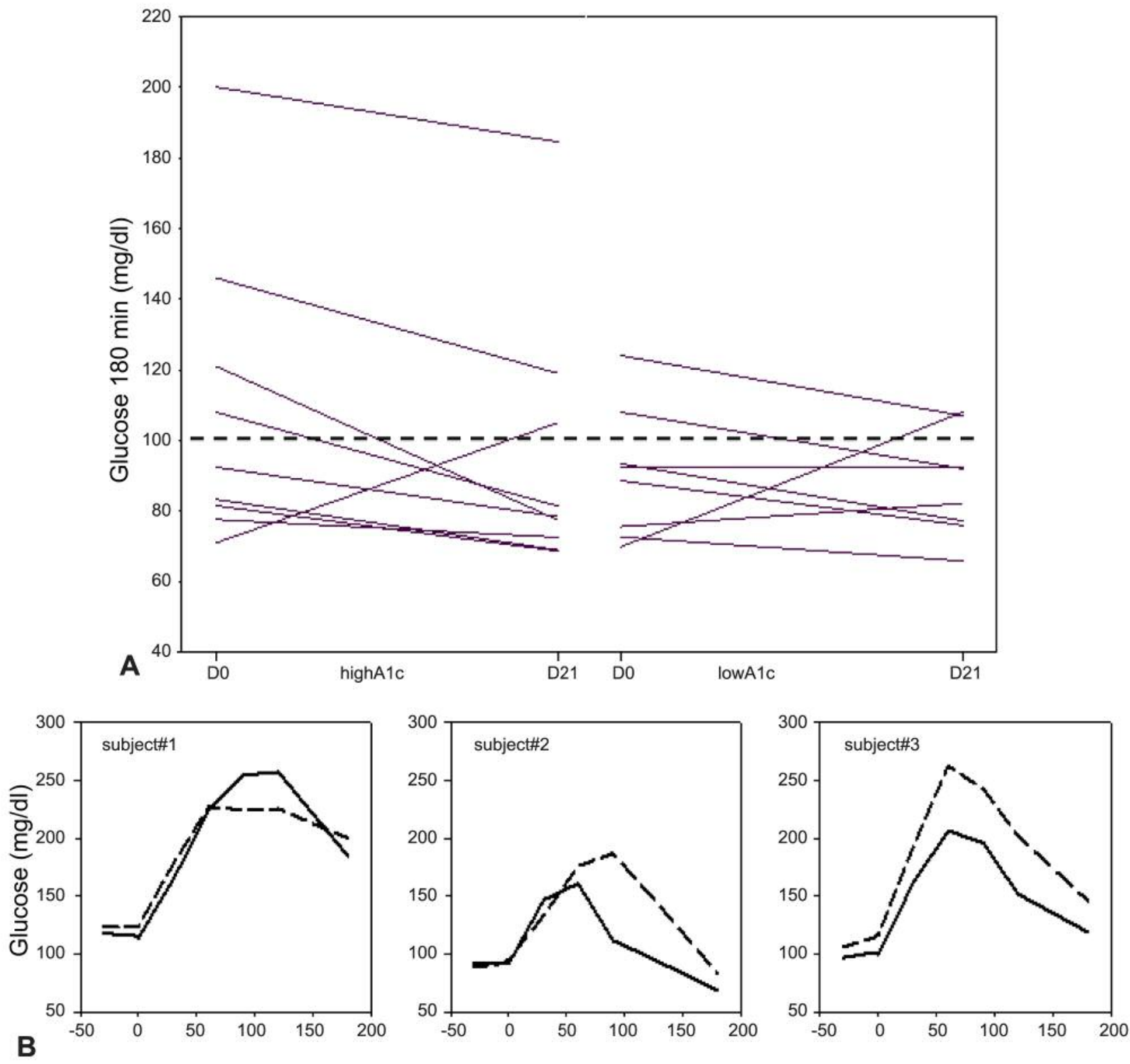

\section{Time ( $\min )$}

Figure 3. Effect of DEA on glucose levels in the oral glucose tolerance test (OGTT). A; comparison of the DEA effect at 180 min in the high and low Alc subgroups. A horizontal line at $100 \mathrm{mg} / \mathrm{dl}$ marks the border between normal and abnormal ranges for glucose. B; OGTT glucose profiles of 3 prediabetic subjects. Day 0; dashed lines, Day 21; solid lines.

$p=0.041)$. This decrease was primarily driven by the high A1c group which exhibited a $7.99 \%$ decrease $(p=0.017 ; p=0.068)$; see also Figure 6A. Likewise, LDL/HDL decreased in all 17 subjects by $6.46 \%(p=0.011 ; p=0.02)$. Among the high A1c subjects, this decrease was $9.8 \%(p=0.008 ; p=0.02)$; see also Figure 6B. The ratios of LDL/triglycerides and triglycerides/HDL did not differ significantly between the high and low A1c groups but several individuals experienced clear improvement (Figure 6C, E). Of interest is the effect of treatment on the ratio of triglycerides/HDL, a predictor of cardiovascular disease (39), which increased by $15 \%$ in the low A1c (from 3.9 to 4.6 post-treatment) but decreased by $11 \%$ (from 3.4 to 3.0 ) in the high A1c group. A significant improvement was also observed in the non-cholesterol HDL/HDL ratio, a predictor of onset of non-alcoholic fatty liver disease (NAFLD) (45), which decreased by $6.6 \%$ in the 

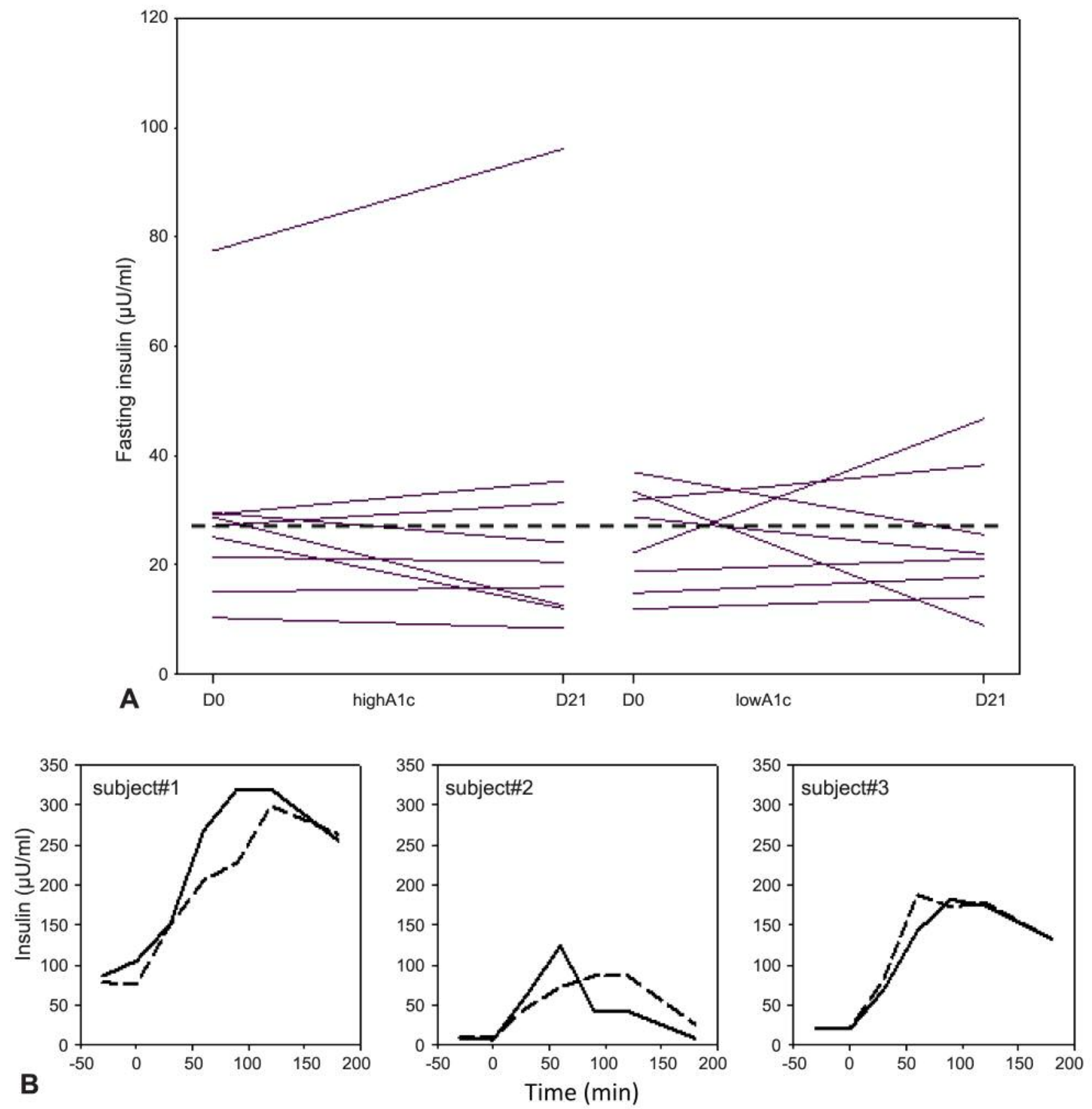

Figure 4. Correlation of the DEA effect on fasting insulin and the Alc levels. A; fasting insulin in the cohort stratified by Alc levels into the high and low Alc subgroups. B; insulin profiles in 3 prediabetic subjects over $180 \mathrm{~min}$. A horizontal line at $25 \mu \mathrm{U} / \mathrm{ml}$ marks the border between normal and abnormal ranges for insulin. D0; dashed lines, D21; solid lines.

entire cohort $(p=0.025 ; p=0.057)$ and by $9.8 \%$ in the high A1c group ( $p=0.025 ; p=0.074)$; see also Figure $6 \mathrm{D}$.

Figure 7 illustrates the lipid panel results for the entire cohort and both the low and high A1c groups. Large differences between the A1c subgroups are evident for HDL/LDL, total cholesterol/HDL and triglycerides. Overall, the lipid panel differences between the high and low A1c groups suggest an adaptive response to DEA.

\section{Discussion}

Data mining using several statistical analytic methods confirmed the statistical significance of DEA effects on markers of IR; glucose, insulin and lipids. For fasting plasma glucose, the DEA effects were significant in prediabetic subjects and those with elevated risk for T2D (the high A1c subgroup and the high fasting plasma glucose group). The 

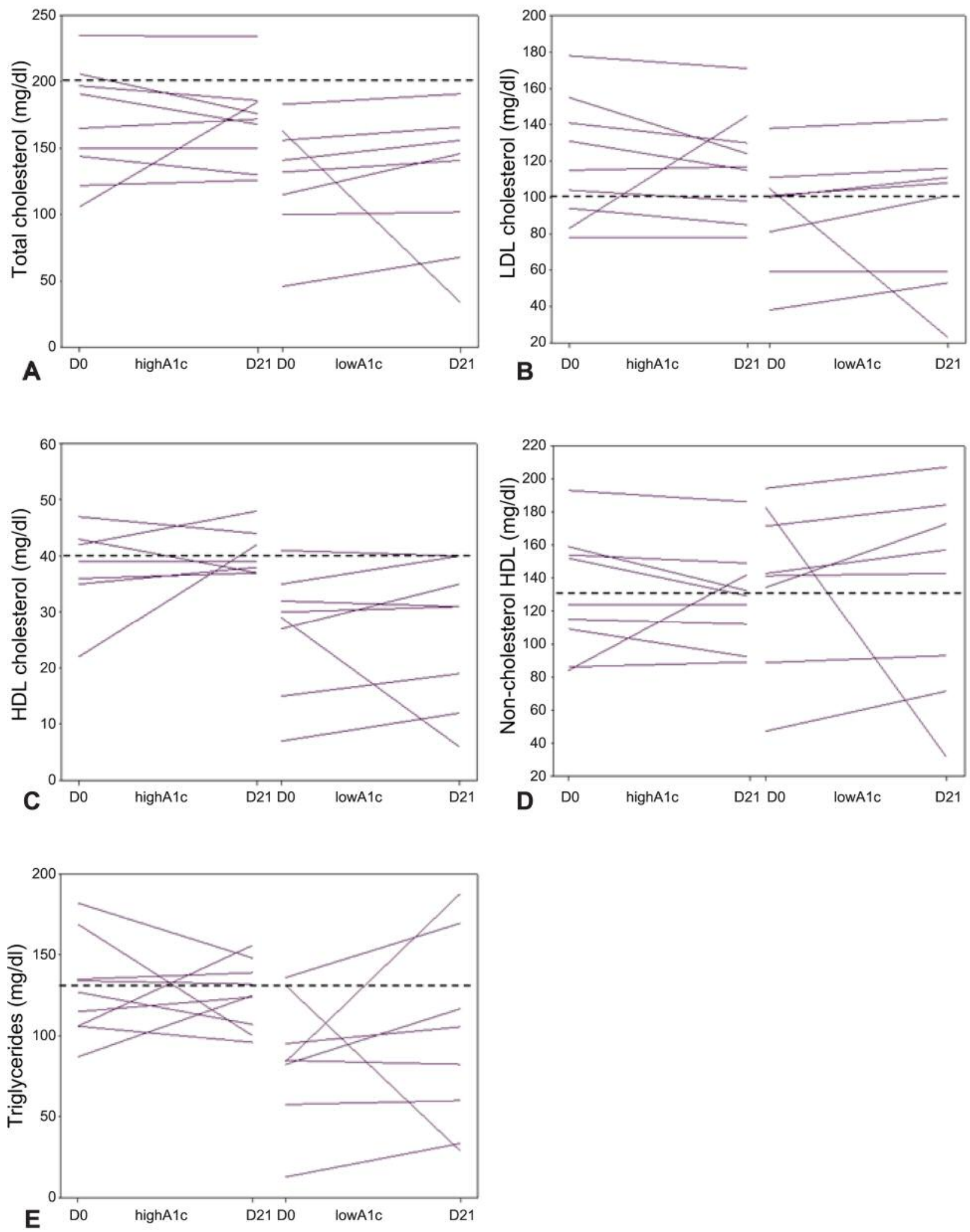

Figure 5. Effect of DEA on single lipid markers. A; total cholesterol, B; LDL cholesterol, C; HDL cholesterol, D; non-cholesterol HDL, E; triglycerides. In all cases, the cohort was stratified by Alc levels into the high and low Alc subgroups. Horizontal dashed lines mark borders between normal and abnormal ranges for the measured endpoints. 

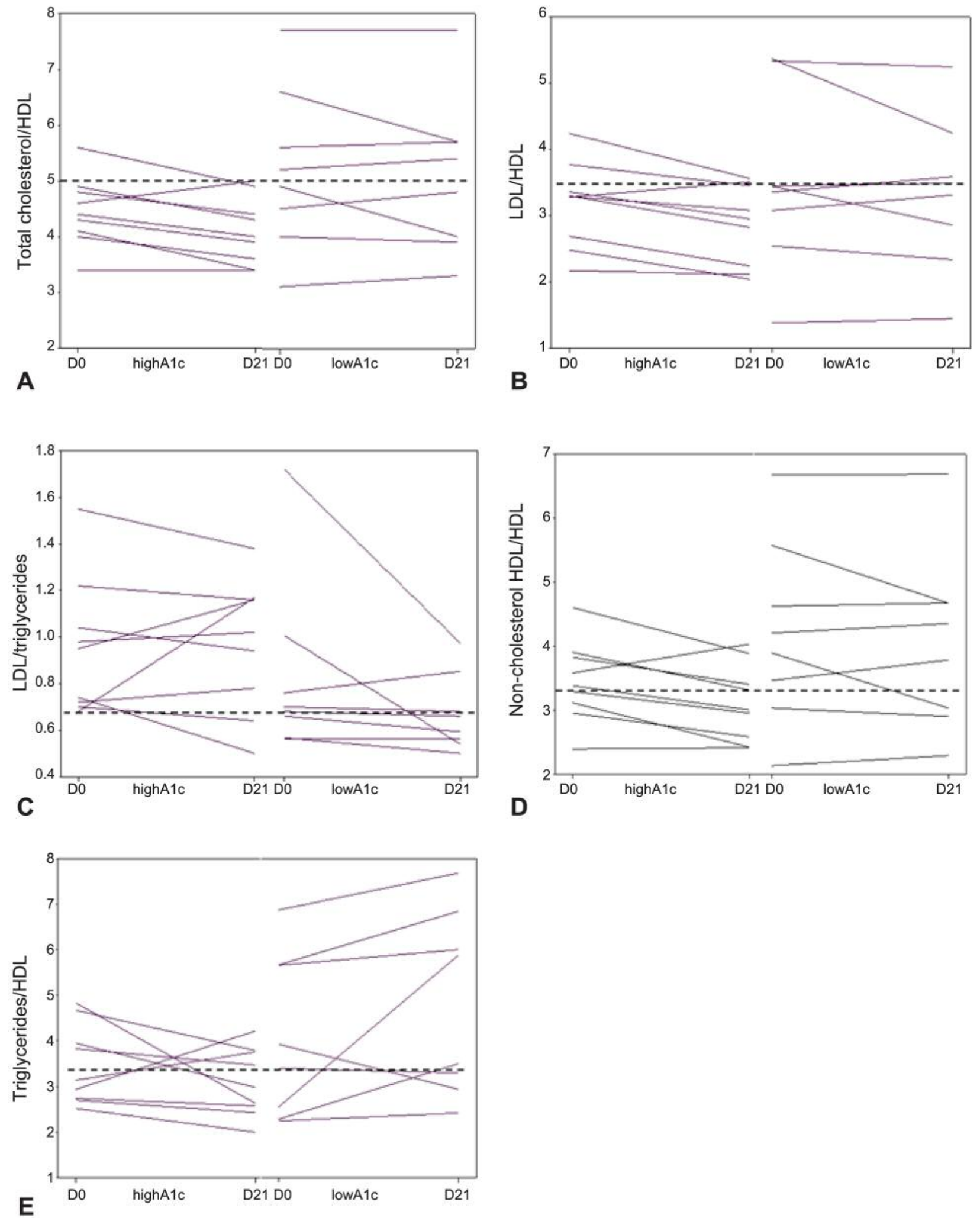

Figure 6. Effect of DEA on the ratios of lipid markers. A; total cholesterol/HDL, B; LDL/HDL, C; LDL/triglycerides, D; non-cholesterol HDL/HDL, $E ;$ triglycerides/HDL. In all cases, the cohort was stratified by Alc levels into the high and low Alc subgroups. Horizontal dashed lines mark borders between normal and abnormal ranges for the measured endpoints. 


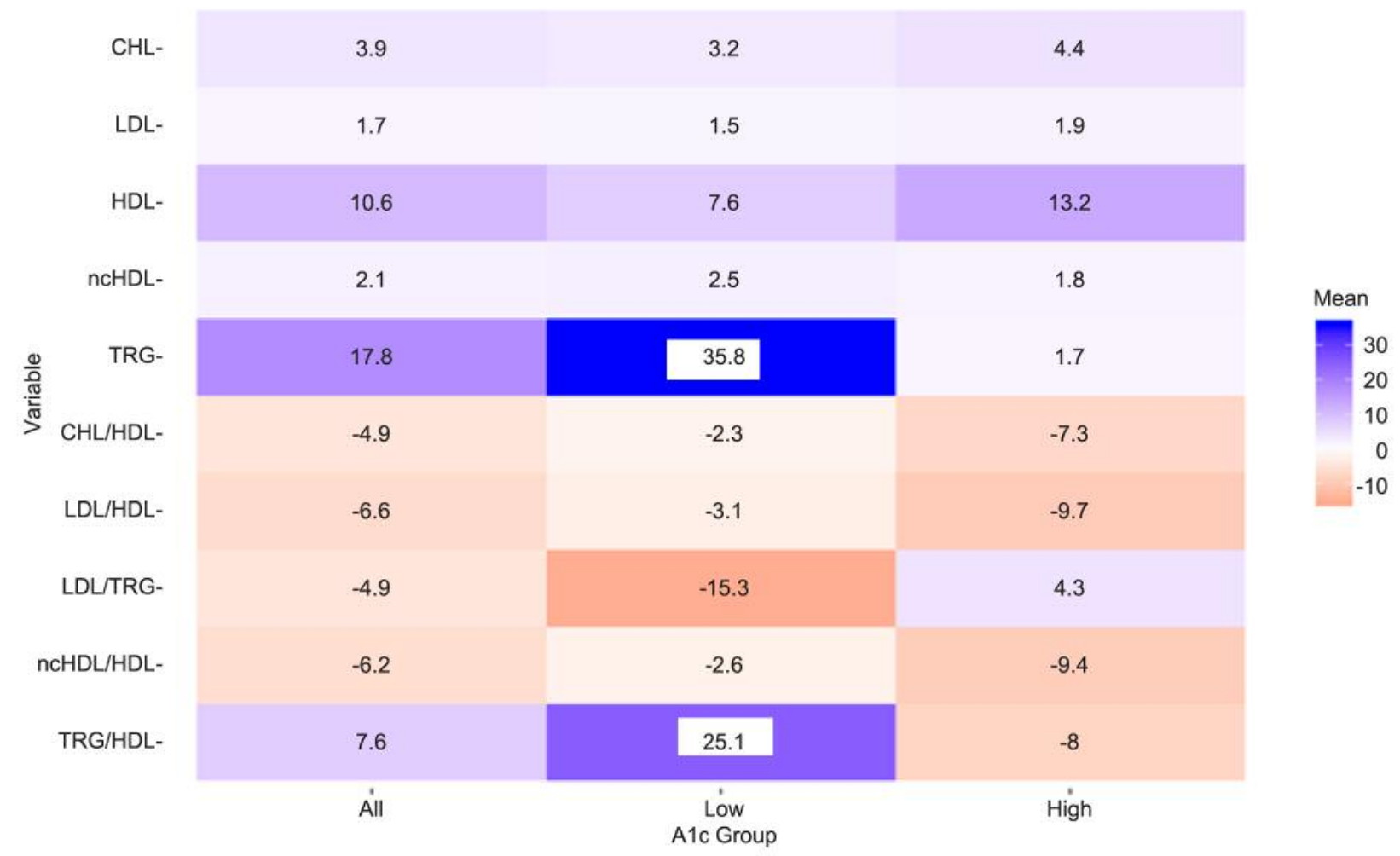

Figure 7. DEA effects on lipid markers in the entire cohort, the high Alc and low Alc subgroups. Mean percentage changes in the levels of the endpoints are presented in the color scale and the numerical values are shown for all endpoints. The blue range corresponds to increased values post-treatment and the yellow/orange range corresponds to the decreased values.

apparent non-responders did not have clinical indicators of T2D or prediabetes and as such would not be considered a population needful of antidiabetic therapy. The discordant responses in the test group suggest that normal subjects do not benefit from DEA and that those with signs of IR show improvements in their clinical indices of IR in response to DEA treatment. The individuals with higher IR experienced even greater benefit from DEA treatment. Subjects classified in the range of $\mathrm{T} 2 \mathrm{D}$ risk or prediabetes evidenced improvement not only in the plasma glucose but also insulin levels. These results suggest that upon DEA treatment the pancreas functions less hard in producing insulin and is less likely to 'burn out' as seen in late T2D (46).

A review of the literature on metformin revealed many similarities and a possible advantage of DEA over metformin based on our data (Table II). For example, in a 28-day study in 16 subjects with T2D, metformin reduced fasting glucose but had no effect on insulin (47). In a meta-analysis of 4750 prediabetic subjects in randomized trials of at least 8 weeks, metformin reduced fasting glucose $(-4.5 \%)$, fasting insulin ($14.4 \%)$, and $\operatorname{LDL}(-5.6 \%)$ and increased HDL $(5.0 \%)$ compared to placebo or no treatment (48). In our 21-day study, fasting plasma glucose decreased by $5.9 \%$ and fasting insulin decreased by $38 \%$. In a 15 -year study, metformin reduced the incidence of diabetes compared to placebo by $17 \%$ and the subset that benefited most included subjects with higher baseline plasma glucose or A1c (49). Our data illustrate a similar trend and we have supporting evidence (50) that DEA will be even more effective in more advanced diabetic pathology.

Neither metformin (51) nor DEA induced hypoglycemia. The effects of DEA on the lipid levels were also qualitatively similar to metformin (47). In particular, DEA significantly improved the LDL/HDL ratio and the decrease of $9.8 \%$ that was achieved in 3 weeks is comparable with an $11.7 \%$ decrease reported after 1 year of treatment with metformin in statinnaïve individuals (52). Oral DEA was well tolerated, while metformin causes severe gastrointestinal side effects in 1 of 4 users and $5 \%$ patients cannot tolerate metformin at all (53).

The proposed uses of metformin go far beyond the first line intervention in T2D. Metformin is touted as a promising treatment for obesity by inducing weight loss (54), and as a drug for cardiovascular disease (55), cancer (56), and life extension $(57,58)$. Our ongoing laboratory experiments suggest the potential application of DEA for these indications. 
Table II. Comparison of diethylazelate and metformin effects on glucose, insulin and lipid markers.

\begin{tabular}{|c|c|c|c|c|}
\hline Variable & DEA & Metformin & Study duration & Reference \\
\hline Fasting plasma glucose & $* 5.9 \%$ decrease (apparent responders) & $4.5 \%$ decrease & 8 weeks (T2D risk) & 48 \\
\hline Hypoglycemia & No effect & Infrequent event & Multiple studies & 51 \\
\hline Fasting insulin & $* 38 \%$ decrease (apparent responders) & $14.4 \%$ decrease & 8 weeks (T2D risk) & 48 \\
\hline HDL & $8.7 \%$ increase & $5 \%$ increase & 1 year $(\mathrm{T} 2 \mathrm{D})$ & 52 \\
\hline Cholesterol/HDL & $* 5.4 \%$ decrease (all), $* 8 \%$ (high A1c) & $9.2 \%$ decrease & 4 weeks (T2D) & 47 \\
\hline LDL & $4.3 \%$ decrease (all), $2 \%$ (high A1c) & $5.6 \%$ decrease & 1 year (T2D) & 52 \\
\hline LDL/HDL & $* 6.5 \%$ decrease (all), ${ }^{*} 9.8 \%$ (high A1c) & $11.7 \%$ decrease & 1 year $(\mathrm{T} 2 \mathrm{D})$ & 52 \\
\hline Side effects & Mild transient diarrhea (1/17 subjects) & Severe gastrointestinal effects & Multiple studies & 53 \\
\hline
\end{tabular}

*Significant effect in this study.

Interestingly, unlike the glucose and insulin effects of DEA in subjects with higher IR, we observed significant improvement in the diagnostic lipid ratios of cholesterol/HDL, LDL/HDL (59) and non-cholesterol HDL/HDL (60) in the entire cohort. These subjects were either overweight or obese and were thus at risk for comorbidities of metabolic syndrome including metaflammation (61), NAFLD and non-alcoholic steatohepatitis (NASH) (62), T2D, cardiovascular diseases, and cancer.

At present there are no approved drugs to treat NAFLD or NASH, and the lipid complications of metabolic syndrome are currently treated with statins (63). We found no overlap in statistically significant endpoints for DEA and statins except for decreased LDL/HDL ratios for DEA (9.8\%; our 3-week study) versus statins [26.7\%; 18-24month study (64)]. However, statins may increase hyperglycemia and risk for T2D (65) especially on a high carbohydrate diet (66) and their adverse effects include severe muscle condition; rhabdomyolysis, further exacerbated by metabolic syndrome (67). Thus, the population that cannot tolerate statins may benefit from DEA treatment that may lower the risk of progressive diseases initiated and driven by dyslipidemia.

Future clinical studies with DEA will address optimization of both the dose and duration of the treatment for prediabetes/T2D and the efficacy of DEA in combination with other drugs and in the frank T2D population. The durability of the response to DEA and its effects on concomitant diseasessuch as subjects with T2D and heart disease or cancer are as yet unknown and need to be examined.

The present study sheds more light on the mechanism of action of DEA. The correlation of the antihyperglycemic and lipid modulating effects of DEA with the degree of IR pathology can be rationalized in terms of the effects of DEA on plasma membrane fluidity, based on our in vitro laboratory experiments (data not shown). An increasing body of evidence suggests that even minor changes of membrane structure and composition affect host immune functions, inflammatory signaling and innate immune responses (6870). Plasma membrane structure can be altered by various diseases $(71,72)$ but also by the diet. It has been proposed that dietary fats and sugars induce alterations in plasma membranes that result in pathological insulin signaling and diminished tissue glucose uptake associated with T2D (73). A small lipophilic molecule such as DEA may diffuse through the plasma membrane $(74,75)$, increase membrane fluidity and trigger metabolic changes that translate into health benefits.

\section{Conclusion}

DEA induced beneficial changes in metabolic markers of IR that are correlated with disease severity. We propose that these effects are achieved via modulation of plasma membrane fluidity using membrane-soluble molecules. Our observations support the development of drugs intentionally designed to modulate membrane physicochemical characteristics as a viable approach for the treatment of diverse human diseases. Given the very long history of oral use of azelates due to their natural occurrence, DEA holds promise as a safe long-term strategy for management of IR and related pathologies.

\section{Conflicts of Interest}

EI and RS are the owners and officers of New Frontier Labs L.L.C., the sponsor of the human study described in the manuscript.

\section{Authors' Contributions}

EI and RS conceived the project, supervised the clinical study and wrote the manuscript. CL performed statistical analysis of the results and reviewed the manuscript.

\section{Acknowledgements}

The Authors are grateful to Richard F. Ludueña, Ph.D. for a critical review of the manuscript. 


\section{References}

1 Streeper R, Izbicka E and inventors; New Frontier Labs, LLC, assignee. United States Patent No. US10,251,857 B2. Azelaic acid esters in the treatment of insulin resistance. USA, 2019.

2 Esposito K, Chiodini P, Colao A, Lenzi A and Giugliano D: Metabolic syndrome and risk of cancer: a systematic review and meta-analysis. Diabetes Care 35(11): 2402-2411, 2012. PMID: 23093685. DOI: $10.2337 / \mathrm{dc} 12-0336$

3 Moghaddam AA, Woodward M and Huxley R: Obesity and risk of colorectal cancer: a meta-analysis of 31 studies with 70,000 events. Cancer Epidemiol Biomarkers Prev 16(12): 2533-2547, 2007. PMID: 18086756 . DOI: $10.1158 / 1055-9965$

4 Huang Y, Cai X, Qiu M, Chen P, Tang H and Hu Y: Prediabetes and the risk of cancer: a meta-analysis. Diabetologia 57(11): 2261-2269, 2014. PMID: 25208757. DOI: 10.1007/s00125-014$3361-2$

5 Koo D, Han K and Park C: The incremental risk of pancreatic cancer according to fasting glucose levels: Nationwide population-based cohort study. J Clin Endocrinol Metab 104(10): 4594-4599, 2019. DOI: 10.1210/jc.2019-00033

6 Giovannucci E, Harlan DM, Archer MC, Bergenstal RM, Gapstur SM, Habel LA, Pollak M, Regensteiner JG and Yee D: Diabetes and cancer: a consensus report. Diabetes Care 33(7): 1674-1685, 2010. PMID: 20587728. DOI: 10.2337/dc10-0666

7 Hernandez AV, Pasupuleti V, Benites-Zapata VA, Thota P, Deshpande A and Perez-Lopez FR: Insulin resistance and endometrial cancer risk: A systematic review and meta-analysis. Eur J Cancer 51(18): 2747-2758, 2015. PMID: 26597445. DOI: 10.1016/j.ejca.2015.08.031

8 Caputo T, Gilardi F and Desvergne B: From chronic overnutrition to metaflammation and insulin resistance: adipose tissue and liver contributions. FEBS Lett 591(19): 3061-3088, 2017. PMID: 28677122. DOI: 10.1002/1873-3468.12742

9 Christ A and Latz E: The Western lifestyle has lasting effects on metaflammation. Nat Rev Immunol 19(5): 267-268, 2019. PMID: 30911129. DOI: 10.1038/s41577-019-0156-1

10 Boden G, Homko C, Barrero CA, Stein TP, Chen X, Cheung P, Fecchio C, Koller S and Merali S: Excessive caloric intake acutely causes oxidative stress, GLUT4 carbonylation, and insulin resistance in healthy men. Sci Transl Med 7(304): 304re7, 2015. PMID: 26355033. DOI: 10.1126/scitranslmed. aac 4765

11 Lustig RH: Fructose: it's "alcohol without the buzz". Adv Nutr 4(2): 226-235, 2013. PMID: 23493539. DOI: 10.3945/an.112. 002998

12 Shelmet JJ, Reichard GA, Skutches CL, Hoeldtke RD, Owen OE and Boden G: Ethanol causes acute inhibition of carbohydrate, fat, and protein oxidation and insulin resistance. J Clin Invest 81(4): 1137-1145, 1988. PMID: 3280601. DOI: 10.1172/ JCI113428

$13 \mathrm{Kim}$ SJ, Ju A, Lim SG and Kim DJ: Chronic alcohol consumption, type 2 diabetes mellitus, insulin-like growth factor-I (IGF-I), and growth hormone $(\mathrm{GH})$ in ethanol-treated diabetic rats. Life Sci 93(21): 778-782, 2013. PMID: 24084046. DOI: $10.1016 /$ j.lfs.2013.09.018

14. Hirakawa M, Arase Y, Amakawa K, Ohmoto-Sekine Y, Ishihara M, Shiba M, Ogawa K, Okuda C, Jinno T, Kato H, Tsuji H, Hashimoto M, Yamamoto T, Arimoto S and Hara S: Relationship between alcohol intake and risk factors for metabolic syndrome in men. Intern Med 54(17): 2139-2145, 2015. PMID: 26328637. DOI: 0.2169/internalmedicine.54.2736

15 Carr RM, Dhir R, Yin X, Agarwal B and Ahima RS: Temporal effects of ethanol consumption on energy homeostasis, hepatic steatosis, and insulin sensitivity in mice. Alcohol Clin Exp Res 37(7): 1091-1099, 2013. PMID: 23398239. DOI: 10.1111/ acer. 12075

16 Sterrett JJ, Bragg S and Weart CW: Type 2 diabetes medication review. Am J Med Sci 351(4): 342-355, 2016. PMID: 27079339. DOI: $10.1016 /$ j.amjms.2016.01.019

17 Smilowitz JT, O'Sullivan A, Barile D, German JB, Lonnerdal B and Slupsky CM: The human milk metabolome reveals diverse oligosaccharide profiles. J Nutr 143(11): 1709-1718, 2013. PMID: 24027187. DOI: 10.3945/jn.113.178772

18 Matsubara T, Tanaka N, Krausz KW, Manna SK, Kang DW, Anderson ER, Luecke H, Patterson AD, Shah YM and Gonzalez FJ: Metabolomics identifies an inflammatory cascade involved in dioxin- and diet-induced steatohepatitis. Cell Metab 16(5): 634-644, 2012. PMID: 23140643. DOI: 10.1016/j.cmet. 2012.10.006

19 Fan H and Fan W: Characterization of key odorants in Chinese chixiang aroma-type liquor by gas chromatography-olfactometry, quantitative measurements, aroma recombination, and omission studies. J Agric Food Chem 63(14): 3660-3668, 2015. PMID: 25797496. DOI: $10.1021 /$ jf506238f

20 Saerens SM, Delvaux F, Verstrepen KJ, Van Dijck P, Thevelein JM and Delvaux FR: Parameters affecting ethyl ester production by Saccharomyces cerevisiae during fermentation. Appl Environ Microbiol 74(2): 454-461, 2008. PMID: 17993562. DOI: 10.1128/AEM.01616-07

21 Kostelenos G and Kiritsakis A: Olive tree history and evolution. In: Kiritsakis A, Shahidi F, editors. Olives and olive oil as functional foods. Oxford, UK: John Wiley \& Sons Ltd, pp. 1$12,2017$.

22 Rahmani M: Food hazards and quality control in table olive processing with a special reference to functional compounds. In: Kiritsakis A, Shahidi F, editors. Olives and olive oil as functional foods. Oxford, UK: John Wiley \& Sons Ltd, pp. 347-352, 2017.

23 Hymowitz T: The history of the soybean. Soybeans Chemistry, Production, Processing and Utilization: AOCS Press, pp. 1-31, 2008.

24 Kwon DY, Daily JW, 3rd, Kim HJ and Park S: Antidiabetic effects of fermented soybean products on type 2 diabetes. Nutr Res 30(1): 1-13, 2010. PMID: 20116654. DOI: 10.1016/j.nutres. 2009.11.004

$25 \mathrm{Kim} \mathrm{J}$ and Chung $\mathrm{H}$ : Components in commercial douchi a Chinese fermented black bean product by supercritical fluid extraction. J Food Sci Nutr 13: 12-17, 2008. DOI: 10.3746/jfn. 2008.13.1.012

26 European Food Safety Authority (EFSA). Opinion of the Scientific Panel on Food Additives, Flavourings, Processing Aids and Materials in contact with Food (AFC) on a request from the Commission related to Flavouring Group Evaluation 10: Aliphatic primary and secondary saturated and unsaturated alcohols, aldehydes, acetals, carboxylic acids and esters containing an additional oxygenated functional group and lactones from chemical groups 9,13 and 30 [Commission Regulation (EC) No 1565/2000 of 18 July 2000]. EFSA J 246: 1-110, 2005.

27 European Commission. Available at: https://ec.europa.eu/food/ safety/food_improvement_agents/additives/database_en 
28 Food and Drug Administration (FDA) of the United States of America. Available at: https://www.accessdata.fda.gov/scripts/ cdrh/cfdocs/cfcfr/CFRSearch.cfm?FR=172.515

29 Food and Drug Administration (FDA) of the United States of America. Available at: https://www.accessdata.fda.gov/scripts/ cder/iig/index.cfm?event=BasicSearch.page

30 Singh B and Saxena A: Surrogate markers of insulin resistance: A review. World J Diabetes 1(2): 36-47, 2010. PMID: 2153742. DOI: $10.4239 /$ wjd.v1.i2.36

31 Bonora $\mathrm{E}$ and Tuomilehto J: The pros and cons of diagnosing diabetes with A1C. Diabetes Care 34: S184-90, 2011. PMID: 21525453. DOI: $10.2337 / \mathrm{dc} 11-\mathrm{s} 216$

32 American Diabetes Association: Diagnosis and classification of diabetes mellitus. Diabetes Care 36: S67-74, 2013. PMID: 23264425. DOI: $10.2337 / \mathrm{dc} 13-S 067$

33 Tyrer S and Heyman B: Sampling in epidemiological research: issues, hazards and pitfalls. BJPsych Bull 40(2): 57-60, 2016. PMID: 27087985. DOI: 10.1192/pb.bp.114.050203

34 Yeung EH, Zhang C, Mumford SL, Ye A, Trevisan M, Chen L, Browne RW, Wactawski-Wende $J$ and Schisterman EF: Longitudinal study of insulin resistance and sex hormones over the menstrual cycle: the BioCycle Study. J Clin Endocrinol Metab 95(12): 5435-5442, 2010. PMID: 20843950. DOI: $10.1210 /$ jc. $2010-0702$

35 Ibrahim MMA, Ghadzi SMS, Kjellsson MC and Karlsson MO: Study design selection in early clinical anti-hyperglycemic drug development: a simulation study of glucose tolerance tests. CPT Pharmacometrics Syst Pharmacol 7(7): 432-441, 2018. PMID: 29732710. DOI: $10.1002 / p s p 4.12302$

36 Warnick G, Kimberly M, Waymack $P$ and Leary E: Standardization of measurements for cholesterol, triglycerides, and major lipoproteins. Labmedicine 39(8): 481-490, 2008. DOI: 10.1309/6UL9RHJH1JFFU4PY

37 Sherifali D, Nerenberg K, Pullenayegum E, Cheng JE and Gerstein HC: The effect of oral antidiabetic agents on A1C levels: a systematic review and meta-analysis. Diabetes Care 33(8): 1859-1864, 2010. PMID: 20484130. DOI: 10.2337/dc09-1727

38 Brambilla P, La Valle E, Falbo R, Limonta G, Signorini S, Cappellini $F$ and Mocarelli P: Normal fasting plasma glucose and risk of type 2 diabetes. Diabetes Care 34(6): 1372-1374, 2011. PMID: 21498787. DOI: $10.2337 / \mathrm{dc} 10-2263$

39 Tuso P: Prediabetes and lifestyle modification: time to prevent a preventable disease. Perm J 18(3): 88-93, 2014. PMID: 25102521. DOI: $10.7812 / \mathrm{TPP} / 14-002$

40 Brunzell JD, Robertson RP, Lerner RL, Hazzard WR, Ensinck JW, Bierman EL and Porter D Jr.: Relationships between fasting plasma glucose levels and insulin secretion during intravenous glucose tolerance tests. J Clin Endocrinol Metab 42(2): 222 229, 1976. PMID: 1262429. DOI: 10.1210/jcem-42-2-222.

41. Gaitonde P, Garhyan P, Link C, Chien J, Trame M and Schmidt S: A comprehensive review of novel drug-disease models in diabetes drug development. Clin Pharmacokinet 55(7): 769-788, 2016. PMID: 26798033. DOI: 10.1007/s40262-015-0359-y

42 Thomas MC: Glycemic exposure, glycemic control, and metabolic karma in diabetic complications. Adv Chronic Kidney Dis 21(3): 311-317, 2014. PMID: 24780460. DOI: 10.1053/ j.ackd.2014.03.004

43 Gerich JE: The importance of tight glycemic control. Am J Med 118(Suppl 9A): 7S-11S, 2005. PMID: 16224937. DOI: 10.1016/j.amjmed.2005.07.051
44 Bluher S and Mantzroros C: Leptin in humans: lessons from translational research. Am J Clin Nutr 89(3): 991S-7S, 2009. PMID: 19176740. DOI: 10.3945/ajcn.2008.26788E

45 Wang K, Shan S, Zheng H, Zhao X, Chen C and Liu C: NonHDL-cholesterol to HDL-cholesterol ratio is a better predictor of new-onset non-alcoholic fatty liver disease than non-HDL-cholesterol: a cohort study. Lipids Health Dis 17(1): 196, 2018. PMID: 30131058. DOI: 10.1186/s12944018-0848-84

46 Donath MY, Ehses JA, Maedler K, Schumann DM, Ellingsgaard $\mathrm{H}$, Eppler E and Reinecke M: Mechanisms of beta-cell death in type 2 diabetes. Diabetes 54: S108-13, 2005. PMID: 16306327. DOI: $10.2337 /$ diabetes.54.suppl_2.s108

47 Eriksson A, Attvall S, Bonnier M, Eriksson JW, Rosander B and Karlsson FA: Short-term effects of metformin in type 2 diabetes. Diabetes Obes Metab 9(4): 483-489, 2007. PMID: 17587390. DOI: $10.1111 / \mathrm{j} .1463-1326.2006 .00624 . \mathrm{x}$

48 Salpeter SR, Buckley NS, Kahn JA and Salpeter EE: Metaanalysis: metformin treatment in persons at risk for diabetes mellitus. Am J Med 121(2): 149-57 e2, 2008. PMID: 18261504. DOI: $10.1016 /$ j.amjmed.2007.09.016

49 Group DPPR: Long-term effects of metformin on diabetes prevention: identification of subgroups that benefited most in the diabetes prevention program and diabetes prevention program outcomes study. Diabetes Care 42(4): 601-608, 2019. PMID: 30877090. DOI: $10.2337 / \mathrm{dc} 18-1970$

50 Streeper R, Izbicka E and inventors; New Frontier Labs LLC, assignee. United States Continuation Patent Application Serial No. 16/627,338. Azelaic acid esters in the treatment of insulin resistance, 2019.

51 Bodmer M, Meier C, Krahenbuhl S, Jick SS and Meier CR: Metformin, sulfonylureas, or other antidiabetes drugs and the risk of lactic acidosis or hypoglycemia: a nested case-control analysis. Diabetes Care 31(11): 2086-2091, 2008. PMID: 18782901. DOI: $10.2337 / \mathrm{dc} 08-1171$

52 Lin SH, Cheng PC, Tu ST, Hsu SR, Cheng YC and Liu YH: Effect of metformin monotherapy on serum lipid profile in statin-naive individuals with newly diagnosed type 2 diabetes mellitus: a cohort study. Peer J 6: e4578, 2018. PMID: 29666753. DOI: $10.7717 /$ peerj. 45784578

53 McCreight LJ, Bailey CJ and Pearson ER: Metformin and the gastrointestinal tract. Diabetologia 59(3): 426-435, 2016. PMID: 26780750. DOI: 10.1007/s00125-015-3844-9

54 Yerevanian A and Soukas AA: Metformin: Mechanisms in human obesity and weight loss. Curr Obes Rep 8(2): 156-164, 2019. PMID: 30874963. DOI: 10.1007/s13679-019-00335-3.

55 Luo F, Das A, Chen J, Wu P, Li X and Fang Z: Metformin in patients with and without diabetes: a paradigm shift in cardiovascular disease management. Cardiovasc Diabetol 18(1): 54, 2019. PMID: 31029144. DOI: 10.1186/s12933-019-0860-y

56 Courtois S, Lehours P and Bessede E: The therapeutic potential of metformin in gastric cancer. Gastric Cancer 22(4): 653-662, 2019. PMID: 30900101. DOI: 10.1007/s10120-019-00952-w

57 Barzilai N, Crandall JP, Kritchevsky SB and Espeland MA: Metformin as a Tool to Target Aging. Cell Metab 23(6): 10601065, 2016. PMID: 27304507. DOI: 10.1016/j.cmet.2016.05.011

58 Kulkarni AS, Brutsaert EF, Anghel V, Zhang K, Bloomgarden N, Pollak M, Mar JC, Hawkins M, Crandall JP and Barzilai N: Metformin regulates metabolic and nonmetabolic pathways in skeletal muscle and subcutaneous adipose tissues of older adults. 
Aging Cell 17(2): e12723, 2018. PMID: 29383869. DOI 10.1111/acel.12723

59 Lemieux I, Lamarche B, Couillard C, Pascot A, Cantin B, Bergeron J, Dagenais GR and Després JP: Total cholesterol/HDL cholesterol ratio vs LDL cholesterol/HDL cholesterol ratio as indices of ischemic heart disease risk in men: the Quebec Cardiovascular Study. Arch Intern Med 161(22): 2685-2692, 2001. PMID: 11732933. DOI: 10.1001/archinte.161.22.2685

60 Wang D, Wang L, Wang Z, Chen S, Ni Y and Jiang D: Higher non-HDL-cholesterol to HDL-cholesterol ratio linked with increased nonalcoholic steatohepatitis. Lipids Health Dis 17(1): 67, 2018. PMID: 29615042. DOI: 10.1186/s12944-018-0720-x

61 Ertunc ME and Hotamisligil GS: Lipid signaling and lipotoxicity in metaflammation: indications for metabolic disease pathogenesis and treatment. J Lipid Res 57(12): 2099-2114, 2016. PMID: 27330055. DOI: 10.1194/jlr.R066514

62 Speliotes EK, Balakrishnan M, Friedman LS and Corey KE: Treatment of dyslipidemia in common liver diseases. Clin Gastroenterol Hepatol 16(8): 1189-1196, 2018. PMID: 29684459. DOI: $10.1016 /$ j.cgh.2018.04.023

63 Binesh Marvasti T and Adeli K: Pharmacological management of metabolic syndrome and its lipid complications. Daru 18(3): 146-154, 2010. PMID: 22615610.

64 Nicholls SJ, Tuzcu EM, Sipahi I, Grasso AW, Schoenhagen P, Hu T, Wolski K, Crowe T, Desai MY, Hazen SL, Kapadia SR and Nissen SE: Statins, high-density lipoprotein cholesterol, and regression of coronary atherosclerosis. JAMA 297(5): 499-508, 2007. PMID: 17284700. DOI: 10.1001/jama.297.5.499

65 Sattar N, Preiss D, Murray HM, Welsh P, Buckley BM, de Craen AJ, Seshasai SR, McMurray JJ, Freeman DJ, Jukema JW, Macfarlane PW, Packard CJ, Stott DJ, Westendorp RG, Shepherd J, Davis BR, Pressel SL, Marchioli R, Marfisi RM, Maggioni AP, Tavazzi L, Tognoni G, Kjekshus J, Pedersen TR, Cook TJ, Gotto AM, Clearfield MB, Downs JR, Nakamura H, Ohashi Y, Mizuno K, Ray KK and Ford I: Statins and risk of incident diabetes: a collaborative meta-analysis of randomised statin trials. Lancet 375(9716): 735-742, 2010. PMID: 20167359. DOI: 10.1016/S0140-6736(09)61965-6

66 Seshadri S, Rapaka N, Prajapati B, Mandaliya D, Patel S, Muggalla CS, Kapadia B, Babu PP, Misra P and Saxena U: Statins exacerbate glucose intolerance and hyperglycemia in a high sucrose fed rodent model. Sci Rep 9(1): 8825, 2019. PMID: 31217552. DOI: $10.1038 / \mathrm{s} 41598-019-45369-8$
67 Golomb BA and Evans MA: Statin adverse effects: a review of the literature and evidence for a mitochondrial mechanism. Am J Cardiovasc Drugs 8(6): 373-418, 2008. PMID: 19159124. DOI: $10.2165 / 0129784-200808060-00004$

68 Fessler MB and Parks JS: Intracellular lipid flux and membrane microdomains as organizing principles in inflammatory cell signaling. J Immunol 187(4): 1529-1535, 2011. PMID: 21810617. DOI: $10.4049 /$ jimmunol.1100253

69 Schoeniger A, Adolph S, Fuhrmann H and Schumann J: The impact of membrane lipid composition on macrophage activation in the immune defense against Rhodococcus equi and Pseudomonas aeruginosa. Int J Mol Sci 12(11): 7510-7528, 2011. PMID: 22174614. DOI: 10.3390/ijms 12117510

70 Goluszko P and Nowicki B: Membrane cholesterol: a crucial molecule affecting interactions of microbial pathogens with mammalian cells. Infect Immun 73(12): 7791-7796, 2005. PMID: 16299268. DOI: 10.1128/IAI.73.12.7791-7796.2005

71 Owen JS, Bruckdorfer KR, Day RC and McIntyre N: Decreased erythrocyte membrane fluidity and altered lipid composition in human liver disease. J Lipid Res 23(1): 124-132, 1982. PMID: 7057101.

72 Kojima K: Molecular aspects of the plasma membrane in tumor cells. Nagoya J Med Sci 56(1-4): 1-18, 1993. PMID: 7898547.

73 Pilon M: Revisiting the membrane-centric view of diabetes. Lipids Health Dis 15(1): 167, 2016. PMID: 27671740. DOI: 10.1186/s12944-016-0342-0

74 Lodish H, Berk A and Zipursky SL: Diffusion of small molecules across phospholipid bilayers. Molecular Cell Biology. 4th ed. New York: W.H. Freeman; 2000.

75 Walter A and Gutknecht J: Permeability of small nonelectrolytes through lipid bilayer membranes. J Membr Biol 90(3): 207-217, 1986. PMID: 3735402. DOI: 10.1007/bf01870127 